\title{
LAYers of NAMing ANd Responsibility in SAKI's ShORT STORIES
}

\begin{abstract}
This study takes as its departure point a comment in Tom Docherty's Reading (Absent) Character about naming and responsibility. It places this notion in the context of Saki's short stories, and through them in the comic context as a whole. General illustrations of Saki's gift for naming characters lead to presentation of three specific stories, "The Schartz-Metterklume Method, "The UnrestCure" and "Shock Treatment", which involve the extra "layer" mentioned in the title, as the main characters receive or take on new names for the duration of the story. The study links the author's gesture of naming to Docherty's comments on responsibility and to the relationship of havoc-wreaker to victim and havocwreaker to self.
\end{abstract}

Key words

Humor; Saki; onomastics; Edwardian literature; responsibility; Perception Theory

\section{Introduction}

I will begin with a brief comment on the naming of the author himself. As his fans know, Hector Hugh Munro took his pen name from the The Rubáiyát of Omar Khayyám:

XLVI.

And fear not lest Existence closing your

Account, and mine, should know the like no more;

The Eternal Saki from that Bowl has pour'd 
Millions of Bubbles like us, and will pour.

CI.

And when like her, oh Saki, you shall pass

Among the Guests Star-scatter'd on the Grass,

And in your joyous errand reach the spot

Where I made One - turn down an empty Glass!

(http://emotional-literacy-education.com/classic-books-online-a/rubai10. htm)

This is a fascinating choice for onomastics. One should also note the similarity between Saki, the name, and sack, the dry white wine that the English began importing from the Canary Islands in the sixteenth century. Saki's "bowl" of wit has always been seen as dry, if not acid. And he certainly put his culture and society "to sack" in his frequent biting comments.

On the other hand, it is probably entirely fortuitous that, for the Sufi poets, Saki represents God. I simply mention it because of an interesting coincidence. Munro's sister, Ethel, begins her "Biography of Saki" in this way:

My earliest recollection of Hector, my younger brother, was in the nursery at home, where, with my elder brother Charlie, we had been left alone. Hector seized the long-handled hearth brush, plunged it into the fire, and chased Charlie and me round the table, shouting, "I'm God! I'm going to destroy the world!" (E. Munro 1930: 635)

There is debate as to whether Khayyám was a Sufi poet (Nasr 2006: 165), and FitzGerald did not mention the notion of Saki as God in the preface to his translation. But the juxtaposition does invite at least speculation.

Besides being so creative at naming himself, Saki is known for, among other things, creating interesting names for his characters. An anonymous reviewer in The Spectator, commenting on the newly-published Beasts and Super-Beasts in 1914, notes his "ingenuity in coining proper names" (Beasts 1914: 61). S.P.B. Mais's chapter on Saki in his 1920 work Books and their Writers points out what he labels "his astounding success in choice of names for his characters" (1920: 317, 321). A.A. Milne, in his introduction to The Chronicles of Clovis that forms part of The Collected Works of Saki of 1926, devotes half a paragraph to Saki's inventions (1926: xi). Another of his biographers, Charles H. Gillen, points out that Saki's names "approached the Dickensian in their combination of aptness and improbability" (1969: 74). And Fred Abrams once did an admirable onomastic study of the story "Filboid Studge" (1971: 287-288).

Such names are not only creative but also practical. Saki's stories are indeed short - the ones that I will explore most completely below are 1783, 2215, and 1744 words long - and Saki was publishing them first in the columns of dailies and weeklies. This publishing context of course influences the creation of char- 
acters. The readership did not see them regularly; Reginald, the Sakian character who appeared the most frequently, made only fifteen appearances in twenty-eight months, from September 1901 to April 1904. A character or character-type who appears so infrequently must have very salient, exaggerated, and constant characteristics. He cannot have too many of them, as increasing complexity would result in increasing difficulty in recognizing or remembering the character. The author must therefore use a certain type of reminder for the reader: Max Nänny refers to "recall devices and mnemonic support reminiscent of the oral epic" (1984: 61, 33). There is thus a certain return, in the writing of the short story (at least in Saki), to the formulaic qualities that Milman Parry, Albert B. Lord and Walter Ong studied in epic poetry $(1982: 23,34,38)$. Oral forms present character epithets systematically linked to one character and easily memorizable for the listener/reader. The exaggerated pranks, the tendency to speak in quips, a typical pose or speech pattern, are also markers used for keeping the character or character-type in the reader's mind from story to story. In these ways, short stories link their characters to distinctive and salient traits.

This tactic is even more necessary given the limited space of the short story. Unlike the epic creator, the short story author cannot afford to use long passages to remind the reader of the character that is reappearing or the type that is being represented in a new character; he must establish the case quickly. After one or two memorable appearances or descriptions, the author has only to reiterate the name or the basic type elements for the reader to find his way. For example, Saki presents a character, Clode, in his "Potted Parliament" (a chronicle of Parliament proceedings in the weeks leading up to the declaration of World War I) who is the wryest of his commentators on the political scene. In later dispatches, Saki has only to insert the mention of Clode - toasting a Parliament decision, for example - to color his text with irony (Saki 1914f: 677-678; Birden 2011: 10). In this way the writer prepares the reader by constructing a limited, predetermined choice of character traits linked to the character which correspond to that character's function. Tom Docherty reminds us that "the reader [...] is not invited in such cases to contribute to the meaning of such characters: such meaning as they have is almost immediately presented in its entirety, and contained within their name" (1983: 49-50).

The comment by Tom Docherty reminds us of the importance of onomastics in character creation. Like the use of oral formulae, the construction of a name contributes to concision. The name serves as a bookmark for the reader of short fiction who wishes to identify the tone of the story quickly: "[the name] gives the reader a point of view on the fiction as a whole [...] it offers a position for the reader to inhabit and from which to see the world of the fiction and the other characters" (Docherty 1983: 74). The importance of remembering the character leads to the creation of distinctive names, and the importance of setting a comic or satiric scene leads to the creation of a name with comic sound and meaning. Docherty tells us that this function of a name is particularly important for a genre like satire because it is the theme of the narrative that is the important element: 
"An essentialist use of the proper name [...] is clearly consonant with a plotoriented fiction, a fiction in which the mechanics of the intrigue subsume the characters into the effecting of a design" (Docherty 1983: 49).

\section{Heroes and their designs}

The "design" in Saki usually opposes a victim to a havoc-wreaker, and for both of these opponents Saki creates heavily significant names. His two main "Brilliant Young Men", as Digamma called them in 1904, are named Reginald and Clovis (1904: 1-2). The names are obviously chosen for their royal or noble consonance:

Reginald: of Saxon origin; "counsel”.

Clovis: of Old German origin; "glorious victory".

(Weekley 1916: 44, 293)

However, if the names are noble, the behaviour of these two characters was seen by their victims and some readers as rather un-noble, even ignoble. Their havocwreaking rejection of the more stultifying elements of society marked them as Nuts, a designation that was a condemnation when coming from the staid English. If these names serve to designate the characters as kings, they are kings of folly. They take part in society for no other reason than to be flies in the gardenparty, players in the game of mobile against immobile, life against death, contingency against stability. They are there to engage in "the play of restlessness upon boredom [...]" (Pritchett 1963: 614).

Clovis's family name, Sangrail, also contributes to the image of nobility suggested above, and adds to Clovis a chivalrous dimension.

Sangrail; another term for the Grail; late Middle English, from Old French sant graal 'Holy Grail'.

(Knowles 2006; http://www.encyclopedia.com/topic/sangrail.aspx; Chambers 2009: 1092)

However, Saki's knight-errant is in search of pleasure, unlike his classical brother who is an emblem of virtue. On the other hand, Clovis mirrors his medieval equivalent because his pranks are often perpetrated in the service of others. The knight helps those in distress, and Clovis does this by bringing out the "danger" contained in adhering to strict conventions. For his victims, however, he is the one who spreads terror, like the sorcerer or dragon. It should also be noted that this name contains the verb "to rail", which Clovis does implicitly against these strict conventions.

To rail: to utter bitter complaint or vehement denunciation; rail at, rail against; to complain about or criticize $[\ldots]$ abusively or bitterly. 
sanguinary; ready or eager to shed blood; bloodthirsty; bloody; involving much bloodshed.

sangfroid; self-possession, poise, equanimity, self-control, nerve, courage, steadiness; calmness or composure, cool-headedness.

(http://dictionary.reference.com/browse/rail+against?qsrc=2446; Chambers 2009: 1007; http://dictionary.reference.com/browse/sanguinary; Chambers 2009: 1092; http://dictionary.reference.com/browse/sangfroid; Chambers 2009: 1092)

The syllable "sang" reminds one of the sanguinary nature of Clovis and the other havoc-wreakers, spilling the "blood" of social mannerisms. It also reminds us of the animal nature of these characters, their "wild", uncivilized side, as seen by their society.

Cyril Skatterly, a minor but effective Sakian havoc-wreaker who appears in "A Touch of Realism" (Saki 1914e: 133-142), continues the tradition of noble names begun with Reginald and Clovis. His first name evokes a monk's or a saint's seriousness and the stern haughtiness of many Russian nobles.

Cyril: of Greek origin; "lord" (kyrios). The name of at least eight saints. (Hanks and Hodges 1994: 74)

At the same time, his last name spells trouble (Skatter/scatters wits). He would like to chase away the narrowness of his society (skat/scat).

Skatterly - to scatter someone's wits (ex. Dickens, Great Expectations, Chap. 17)

Skat/scat! - to go off hastily; to go away; to run off (often used in the imperative).

(http://dictionary.reference.com/browse/scat; Chambers 2009: 1100)

Saki's one regular "Brilliant Young Woman" havoc-wreaker is Vera Durmot. She appears in "The Open Window" (Saki 1914b: 50-55), "The Lull" (Saki 1914a: 73-81), "A Touch of Realism" (Saki 1914e: 133-142), and "The Quince Tree" (Saki 1914c: 183-189). Her first name also has noble connotations. It shows her "faith" in her efficacy, and of course contains the suggestion of "verity", truth, her truth of pursuit of pleasure.

Vera: Russian name, meaning "faith", [...]. It coincides in form with the feminine form of the Latin adjective verus truth [...]

(Hanks and Hodges 1994: 329)

She has lively verbal powers (durmot/mot dur), and she is a tough cookie (dur à cuire). 


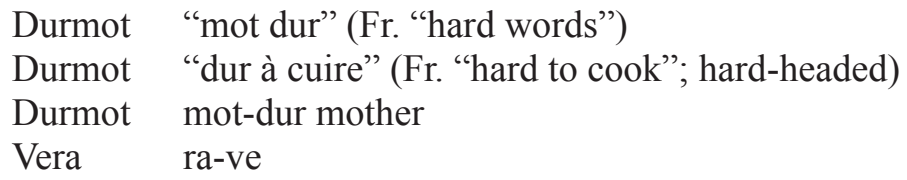

She is the mother of all flappers (mot-dur/mother) in Saki's world, the female representation of destabilization. Like Clovis she raves (ve-ra/rave) against society's rigidity. These examples and others examined below show how Saki uses names to concentrate the essential aspects of his characters and convey them to the reader.

\section{Heroes and renaming}

We can see by these examples that Saki's choice of names for his comic heroes is fairly astute. What is doubly effective is his or his characters' choices for renaming, which continue the onomastic play. On three occasions in particular, the havoc-wreaker takes on another identity. In this context, it is interesting to note Tom Docherty's tendency to link this question of onomastics to that of polynomalism as a sign of another modern phenomenon which he calls "irresponsibility and subsequent loss of self in much recent experimental fiction" (1983: 77). He gives Wilde's The Importance of Being Earnest as the origin of this effect. The question of loss of self I will deal with at the end of this study. The question of naming as a source of irresponsibility is at the heart of several Saki stories; I will use "The Schartz-Metterklume Method", "The Unrest-Cure", and "Shock Tactics" to illustrate this. I hope to demonstrate that, in conjunction with mendacity, a false name adds to the extravagance of the havoc-wreaker's prank and doubles its effect.

"The Schartz-Metterklume Method" begins with a false name imposed on a flapper (Saki 1911: 2). Lady Carlotta (an upper-class woman who nonetheless shows the sensibilities of a havoc-wreaker) is left behind in a country train station, then addressed by a woman who had come to collect her new governess and who takes her for that person. "Carlotta" is a rather exotic name for an Englishwoman.

Carlotta: of Italian origin; variant of Charlotte.

Charlotte: French feminine diminutive of Charles.

Charles: originally from a Germanic word meaning "free man", cognate with Old English ceorl man. (The modern English words churl and churlish are derived from this $[\ldots])$. churl: an ill-bred surly person. churlish: ill-mannered or rude. (Arthur 1857: 292, 94; Hanks and Hodges 1994: 55, 61, 60; Chambers 2009: 224) 
It is the aspect of freedom which applies most to this young woman. The name easily evokes her reasons for missing her train: her compassion for animals made her leave it to remonstrate with a cart driver (Carlot/cares a lot). The text tells us that she is usually inclined to quarrel (Carlot/quarrel a lot) with her friends. She also shows the force of decision and force of character associated in her society with men (CARLotta). Such a woman would indeed be seen as "churlish" by the more staid members of society. Suddenly she is obliged to adopt the name of the governess: Miss Hope. The name speaks for itself; the woman designated by it is to be the hope of the mistress of the house which is "employing" her. Lady Carlotta accepts this mistaken identity in order to fill her time until the next train.

It must be said that her employer has already shown ripeness for victimization. Her name, Mrs. Quabarl, suggests a woman who could also tend to quarrel (Quabarl/quarrel), which could explain the need for a new governess. But her character is dominated by pusillanimity (quabarl/querulous). She is a nouveauriche woman who can be made a stooge of easily (barl/larb, as in the French "larbin", stooge). She succeeds in taking hold of Lady Carlotta immediately because at first glance she seems imposing (barl/to barrel down on); however, she easily breaks down (barl/bawl). The signification of this name carries even more weight by the fact that she has no first name; nor does her husband. Both of them are timorous, semi-anonymous beings during the story, incapable of imposing even their identities through the uttering of each other's first names.

The nice "Miss Hope" dominates the Quabarls and the household as soon as she takes up her supposed "service". On every subject, from automobiles to languages, from wine to spankings, she leads the way and has her fun with them riotously. Hidden behind her gentle name, she can create this joyous farce with impunity; the only possible result for her will be to be "fired" and able to continue her voyage. Thus, as Docherty would have it, she is not "responsible" for the effect that her attitude could have.

The farce culminates in the use of her method for teaching history, the "SchartzMetterklume Method". The weight of this name already gives it an aspect of serious intellectualism which would baffle the family.

Schatz n. treasure

Schatzen v. to estimate

Schar n. horde

Satz n. game

Last name Scharz/Schartz: nickname for a juggler, from Middle High German scharz 'move (of a chess piece)'

(http://www.wordreference.com/; http://answers.yahoo.com/question/index ?qid=20090219001106AACQ6mT)

It is important to take into consideration a game of polyglot onomastics when dealing with Saki. He spoke fluent French, Russian, and German. He worked as foreign correspondent in the Balkans, St. Petersburg, Vienna, and Paris. While 
in Paris, according to his sister, he published articles written in French in Parisian dailies (E. Munro 1930: 688). The general staff tried to coax him out of the trenches during World War I to give him a position as an interpreter; unfortunately he refused (Langguth 1981: 254-255, 269). There is a short story in the Bystander on 20 September 1916 called "Lilian's Lonely Soldier". It is very Sakiish, but more subdued; It is signed "Nitchevo", the Russian word for "nothing" (Nitchevo 1916: 511-512). A multilingual basis for Saki's onomastics is therefore quite likely; one often finds play on these languages in his texts other than in the names. It may be difficult to demonstrate if Saki was familiar with all of the possible meanings of foreign words, but it is impossible to demonstrate that he was not. It is certainly likely that he chose this name for the method because of his knowledge of German and not simply to imitate the sounds of the language. Let us consider all the possibilities, for the sake of the richness that they afford to the onomastic play.

The onomastics of German reading suggests the "treasures" (Schatz) of inspiration that Lady Carlotta can draw on, after having "estimated" (schatzen) the true value of these bragged-about children. She can descend on them like a heathen "horde" (Schar) and make all her "moves", play all her "games" with the youngsters (Satz, Schartz). English onomastics reflects its inventor's "sharp" wit (schartz/sharp) and her domination of the family (metter/master).

The final syllable of "Metterklume" gives us more riches of onomastic play:

Krume n. crumb

Klemme n. clip

in der Klemme sein exp. to be in a fix

Last name Klum;

klumm adj. short, limited

geldklumm exp. short on money

klamm sein exp. strapped for cash

Klume - enclume Fr. "anvil"

(http://www.wordreference.com/; http://german.about.com/od/names/a/gerNames_2.htm)

With her "method", "Miss Hope" reduces the children to "crumbs" (Krume), "puts them in a fix" (in der Klemme sein), and underlines their "shortcomings" ("klumm" as limited). French onomastics makes of the children the "anvil" (enclume) on which Lady Carlotta pounds (with a cricket bat) in order to forge their minds.

Thus the children become also the victims of the farce, centered now on this method which requires them to act out historical events in order to learn them; for the first (and last) lesson, the boys, Claude and Wilfrid, must kidnap the lodgekeeper's daughters in order to reenact the rape of the Sabine women, while the Quabarl daughters, Irene and Violet, play allegories of Rome. The children's 
names show the optimism expressed by the parents in choosing them, as they are linked to peace and to aristocracy.

Claude: of Latin origin; "celebrated, distinguished, illustrious".

Wilfred: of Saxon origin; "much peace". Variant Wilfrid.

Irene: of Greek origin; "peace".

Violet: of Latin origin; "purple". From the name of the flower and the colour. (Charnock 1882: 25; Arthur 1857: 289; Weekley 1916: 216; http://www. thinkbabynames.com/meaning/0/Violet; Hanks, Hardcastle and Hodges 2012: .e4336)

However, one can suggest less lofty interpretations of the names.

Claude - cloying

Wilfrid - willful

Irene - I scream

Violet - violent, violating

These insufferable children are given their chance to suffer during this short lesson. The girls endure the discomfort of their position on the staircase, while the boys are threatened with the bat and with retaliation by the two kidnapped girls.

Mrs. Quabarl interrupts the lesson when she hears the kidnapees' uproar, and demands an explanation from "Miss Hope". The latter explains her "method", and adds: "if, thanks to your interference, your boys go through life thinking that the Sabine women ultimately escaped, I cannot be held responsible." In this way the theme of irresponsibility receives a direct echo in the text. Lady Carlotta, alias Miss Hope, is in fact not responsible for the instruction of these children, any more than she is for the children's false view of the historical incident. She is not at all responsible for anything that "Miss Hope" would decide to do. Through this play on names, Lady Carlotta's comment is infused with irony. She is fired and the real governess arrives, to the great relief of the family.

Unlike Lady Carlotta, Clovis chooses his false name himself as he constructs the false situation of "The Unrest-Cure" (Saki 1910a: 1, 2). Clovis is on his way to a small village to stay with a relative. In the train he overhears a conversation in which James Huddle, a provincial stay-at-home, talks about the rut he and his sister have fallen into and their inability to get out of it. Clovis decides to visit him in order to apply his "therapy" on the pair, and writes down his address.

Mr James Huddle

The Warren

Tillfield near Slowborough

The name and address of Mr. Huddle clearly evoke the stagnation of his life; he "huddles" at home, far from the bustling world, in a cocoon of home life, resem- 
bling a rabbit in a Warren (the name of his house). This rabbit lives in Tillfield, a name that suggests plodding behind a plow, near Slowborough, a village which is not ready to offer him many lively joys. Mr. Huddle thus shows himself to be in a situation of cause and effect; Slowborough creates people slow to change, living in warrens.

In the middle of this placid environment, a bomb lands in the form of the announced visit of the Bishop that same afternoon. The very announcement begins to trouble the routine of the Huddles; they will have to curry the cold duck even though it is not the day for it, and their reading hours will be interrupted. Clovis then appears as Stanislaus, the Bishop's secretary, to arrange things.

Stanislaus: variant for Stanislas.

Stanislas: Latinized form of an old Slavonic personal name composed of the elements stan government + slav glory.

(Hanks and Hodges 1994: 308)

The exotic name that Clovis has chosen suggests Eastern Europe and its repeated turbulence. It shows Clovis's determination to "govern" these timid people, all while he "glories" in his capacities as havoc-wreaker. It also marks the loss (laus) of the Huddles' tranquility (stan/stagnation) for the rest of the day and night. In this way Clovis begins immediately to break their habits, mounting an assault against the most complete representation of habit in the Sakian repertoire. A telegram addressed to "Prince" Stanislaus adds more exoticism to the character and reinforces his ties with the east. This prince continues to pinch (prince/pincer/ pinch) the Huddles' immobility by announcing the purpose of the Bishop's visit: the massacre of all the local Jews. This "news" is corroborated by the first arrivals of Jewish families, invited there by telegram. During this time the Bishop is supposed to be shut up in the library putting the last touches on the plot with Colonel Alberti, whose name also reminds one of a geographic area containing periodical anarchy.

After having indicated to the Huddles where the assassins are hiding, ClovisStanislaus leaves them to their apprehension and returns to the relative who had invited him to the village in the first place. Abandoning his victims this way is his last act of irresponsibility, after that of invading them and of inventing the Bishop and the massacre. With it he abandons the name and the other irresponsibilities that went with it. By leaving behind Stanislaus, Clovis goes toward the position of responsible young man he must occupy at the relative's; he changes for dinner, a proper upper-class gesture. We also see here that Clovis's irresponsibility combines with the usual havoc-wreaker habit of being absent at the dénouement of his prank; Clovis has been gone for a long while when the Huddles discover the joke (Birden 1996: 48-51). In addition, we see that Clovis has conducted his "cure" as much for himself as for the Huddles, as he was worried about being bored in the country. At the same time as he cures them of stagnation, he wards off his ennui. Through lies and exaggeration, Clovis and Lady Carlotta do battle with the 
boredom which threatens the tidy middle class, taking advantage of the situation to create a sprightly prank from the richness of their imaginations.

In "The Unrest-Cure" Clovis is absent and content to highlight the fault and not his own cleverness at revealing it. He prepares the catastrophe and is happy to know that it has happened, without needing to see it, let alone boast of it in the end. On the other hand, in "Shock Tactics", Clovis creates a fabric of lies which presents a different manner of proceeding than usual (Saki 1919: 217-226). Here he allows himself to comment on the exposed fault in a more direct fashion. The reader does not need this commentary, as he has already seen through the narrative what fault Clovis is attacking; instead, Clovis feels that it is necessary to bring the point home to the person concerned. The attack is thus more direct, holding the ineptitude up to the person perpetrating it, which is rare in Saki.

As often happens, Clovis, the "knight-errant of comedy" chasing his "grail" of liberation from a stifling society, comes to the aid of a friend with this prank. The friend is Bertie Heasant, who is in love with Ella.

Albert: of Old German origin; "all bright, famous".

Ella: of German origin; ali other, foreign. Also possibly means "entire" $($ Alia = "all") or (Hebrew) "goddess".

(Arthur 1857: 50; Hanks and Hodges 1994: 101; Cresswell 2003: 111; http:// www.thinkbabynames.com/meaning/0/Ella)

Bertie, the "noble" son of Mrs. Heasant, is a "pretty" boy (Bertie/pretty) who shrinks when confronted with his mother's disapproval. He is "hesitant" (Heasant/hesitant) to confront her. His "goddess" is the "foreigner" Ella, unknown to Mrs. Heasant, a person who would be seen as "hellish" (Ella/hell) by this woman.

Bertie's romance with Ella is clouded by the fact that Ella cannot write to him; his mother opens all letters that come to the house. The descriptions given by the narrator and by Bertie reveal a woman still living by Victorian strictures, treating her children's activities as dissipation or licentiousness. Her choice of "Albert" for her son's name shows her conservative, monarchist tendencies. Mrs. Heasant's authority is based on what her generation perceives as the negative development of the succeeding generation. She represents a type that was prevalent at the time, mistrustful of all contemporary European art yet never having seen a single example of it and never deviating from the conviction that France was an immoral and corrupt country (Hynes 1968: 309-310). She has been given a name suggestive of her lack of taste ("peasant") and a restrictive - and vociferous - attitude ("hissing") which is quickly taken down by Clovis's ruses. Her plaintive tone after her discovery of the ruse shows, more than anything, how much she is part of a precise comic class outlined by Susan Purdie: "[those] illegitimately, and therefore ineptly, holding their power" (Purdie 1993: 65).

Mrs. Heasant wishes to "watch over" her children, "protecting" them from the "pernicious" influences of modern life. Unfortunately, Bertie likes modern life, but has found no solution except to ask friends to pass letters between himself and 
Ella. Ella is quite displeased by the situation, wishing to be "entire" in her love and its expression, and is becoming impatient. At this point, Bertie mentions the problem to Clovis, who decides to take matters into his own hands.

The offensive starts with a mysterious letter signed "Clotilde".

Clothilde: from a German female personal name composed of the elements hlōd famous + hild battle.

(Hanks and Hodges 1994: 68)

Thus Clovis announces his intention of "doing battle" against the stifling Mrs. Heasant. He is also playing on his own name; historically, Clovis and Clotilde were the first Christian king and queen of a united France.

"Bertie, carissimo," it began, "I wonder if you will have the nerve to do it: it will take some nerve, too. Don't forget the jewels. They are a detail, but details interest me.

"Yours as ever,

"Clotilde.

"Your mother must not know of my existence. If questioned swear you never heard of me."

The letter contains hints about jewels and audacious deeds. Mrs. Heasant's reaction to this shows how much she clings to old values: "That any one wearing the exotic name of 'Clotilde' should write to Bertie under the incriminating announcement 'as ever' was sufficiently electrifying [...]." Before even thinking about the implied intrigue, she is already shocked by a familiar form of address and an exotic name. A second letter arrives and congratulates Bertie for accomplishing the deed:

"So you have really done it!" the letter abruptly commenced; "Poor Dagmar. Now she is done for I almost pity her. You did it very well, you wicked boy, the servants all think it was suicide, and there will be no fuss. Better not touch the jewels till after the inquest.

Clotilde."

Mrs. Heasant is now in a paroxysm of indignation, and further destabilized by the strange name Dagmar.

Dagmar: of Scandinavian and Old German origin; "celebrated soldier". A royal name in Denmark.

(Charnock 1882: 29; http://www.thinkbabynames.com/meaning/0/Dagmar)

Clovis enlists this fictional victim in his "battle" against Mrs. Heasant. By evoking royalty once more, Saki hints at a form of regicide. In addition, Clovis (and Saki) embed "daggers" in Mrs. Heasant's timorous heart with this news of the 
"victim". In this way he wants to "bring into daylight" (Dagmar/dag/tag/day) Mrs. Heasant's interference in Bertie's life.

Bertie, who knows nothing of Clovis's ploy, suspects him nonetheless, as he is familiar with Clovis's pranks. However, he does not reveal his suspicions, simply allowing his mother to go from crisis to crisis. Only after the arrival of a third letter does he admit having understood the trick:

"DEAR BERTIE," it ran; "I hope I haven't distracted your brain with the spoof letters I've been sending in the name of a fictitious Clotilde. You told me the other day that the servants, or somebody at your home, tampered with your letters, so I thought I would give any one that opened them something exciting to read. The shock might do them good."

"Yours,

"Clovis Sangrail."

Bertie's contrite mother calms down, and Bertie takes advantage of the moment to come out of his bedroom, in which he had locked himself, and threaten to go for a doctor. The implication that his mother is not in her right mind and the ridicule that she would be subjected to if word got out about the hoax convince her to offer to stop reading Bertie's letters in exchange for his silence. Clovis's lies thus rout an adversary representing one aspect of Victorian and Edwardian conventions. This act does not constitute correction, as Bergson's arguments in Le rire suggest (1970: 395) and as Robert Drake expresses it: "jarring of the self-deceived into sanity" (1960: 72). Mrs. Heasant does not react out of a new awareness, the scales do not fall from her eyes, she does not see the falseness of her ideas; she acts out of fear of ridicule. Bergson affirms that the victim of laughter betters himself once he recognizes his fault. On the contrary, Clovis's implicit laugh and the possible laugh of the doctor do not cure Mrs. Heasant, who recognizes only the need to avoid the arrival of the doctor, representing that society which is supposed to produce this beneficial correcting laugh (Bergson 1970: 395). She gives in to save face, not through any kind of repentance or intention of abandoning her principles; thus she remains essentially unconscious of her faults. The limited space of the short story also does not permit character development in any extensive way (Birden 1996: 157-158).

However, like all those who share her mentality, Mrs. Heasant reveals awe faced with a havoc-wreaker and his nimbleness at creating lies. The Victorian, having lost his imagination through pursuit of earnestness, has bequeathed to the Edwardian an imagination that has only begun to gestate and which therefore cannot identify true and false in concoctions born of the imagination of those who have developed more quickly. In this context, Bertie's comment to his mother is significant: "no person in his right mind would have believed all that rubbish". This young man is not of havoc-wreaker fiber; otherwise he would have found a creative solution to the problem himself. But he can recognize and appreciate the acts of imagination of the havoc-wreakers. 
Returning to the question of Clovis's unusual direct attack, it is true that Clovis avoids mentioning Mrs. Heasant directly in his last letter. However, he makes it quite clear that he was reacting to what he considered reprehensible for different reasons than the average Edwardian would mention. Mrs. Heasant thus sees clearly that she is the target of Clovis's hoax. This is the one instance in Saki's work in which a havoc-wreaker shows that he is wreaking havoc and that a victim is aimed at. We can see that Clovis also does this quite confidently; he shows that he believes in the success of his ploy when he dares to indicate that it comes from Bertie's comments. This detail could simply have given Bertie even more trouble, and perhaps would have caused Mrs. Heasant to quarantine Bertie from undesirable friends. Clovis's revelation of Bertie's willingness to discuss his difficulties with others shows he is confident that his attack has created the proper effect.

In a sense, this gesture shows Clovis's sense of responsibility. He suggests someone who has taken on a task after weighing the elements of it. He could thus be seen as differing, in this instance, from the other examples analyzed. But, as ever in the game of naming and renaming, it is the new name that shows the insouciance. "Clotilde" is the irresponsible one, egging Bertie on to recklessness. At the same time, she washes her fictional hands of any mischief that Clovis cares to invent, and vice versa. Secondarily, Bertie is not irresponsible, but he is not responsible for the death of Dagmar, or for his difficult situation with Ella.

\section{Minor examples and reasoning}

There are many other examples of effective naming in Saki's works, and I will cite a few more before making observations about the general phenomenon of irresponsibility. As I indicated at the beginning, Saki was writing with a set of limitations: time and the reader's exposure to the characters and their activities. There was another restraint in which he had to operate: Gillen suggests that "In inventing these unlikely names Munro may have been motivated by the stringent British libel laws [...]" (1969: 74). Certainly, Mrs. Packletide ("pachyderm"), Loona Bimberton ("loony") and Waldo Plubley ("wad of blubber"), three other not only noteworthy but recurring victims, could possibly have been acquaintances of his.

Ethel Munro indicates in her biography of Saki that one of their aunts is parodied in "The Sex That Doesn't Shop" (Saki 1909: 2), and that many of the characters in Beasts and Super-Beasts were recognizable. She indicates that reviewers actually gave clues to the identity of some of the characters in Saki's first novel, The Unbearable Bassington (1930: 677, 694). For all that some of the personages could be identifiable, Saki could not risk definitive identification. And he may have been aware, as Joan Didion is, that "writers are always selling somebody out" (1979: xiv). He could realistically wish to avoid recognition by what Peter Bilton calls "Sheep-like people, their passions at third- or fourth-hand, ignorant of uncertainty or landslide, [...]" (1966: 441) of their use as butts. 
Incidentally, one of the names cited above can also illustrate the dangers of anachronism. Loona Bimberton can be "loony", as the adjective was present by the mid-nineteenth century, but she cannot be a bimbo, because that term had its first documented use in 1919, and referred to men at that time. By the same token, another character named Gilpet would attract the interpretation "git", but the term is from the 1940s. Time therefore spoils some of the fun of onomastics.

Saki could not avoid recognition, but seemed to wish to reduce the effect of it, when he parodied the politicians of his time, who were particularly protected from attack by the press. For example, the pointed political satire "Ministers of Grace" exists in two versions. The first, published in The Bystander in 1910, used the real names of certain politicians of the period (Saki 1910b: 432-434). When later it was included in The Chronicles of Clovis, not only was the story rewritten and enlarged, but the names were all disguised. James R. Thrane feels that this was done to avoid possible legal charges (Thrane 1971: 141). Unfortunately, he does not explain why, in that case, the first version could have appeared. I would suggest that there were usually more readers for book versions than for magazine versions, and that a magazine was seen to be more ephemeral than a book. Whatever the reason, the names are systematically substituted. Winston Churchill is Quinston, Hugh Cecil is Hugo Sizzle, Lord Curzon of Kedleston is Kedzon, David Lloyd George is Mr. Ap Dave, Arthur Balfour is Halfan Halfour, Hensley Henson is Coxley Coxon, and Rosebery is Thistlebery (Saki 1912a: 266-285). Also in the second version appears Sadbury, representing the editor and chocolate maker Cadbury. Saki continues here a practice that he had started with "The Political Jungle-Book" in 1902. For example, in one episode of this series Rosebery is designated as "The Lone Wolf" because of his complete refusal to toe the party line (Saki 1902a: 2). Balfour is represented in his usual languorous attitude in the guise of the tiger Sheer Khan't (Saki 1902b: 3). His form of vacillation gives the beast his name; he is Sheer Can't (refusal) or Sheer Cant (affected (and meaningless) phraseology, with no aim). Finally, Lloyd George appears as the rogue elephant Runamukki.

These different examples show at the same time Saki's ingenuity in inventing or reworking names and another aspect of the necessity to do so.

\section{Irresponsibility and its effects}

The discussions of "The Schartz-Metterklume Method", "The Unrest-Cure", and "Shock Tactics" with their focused characters and their mendacity and irresponsibility show how difficult it is to accept Drake's analysis of the Sakian havocwreakers, to which he accords "knowledge of what is really going on in the world about them"; "their solution to the problem [is] that of bringing order and sanity to the disordered [...]" (Drake 1960: 67). One must ask one crucial question when faced with these comments. Just what world is Drake talking about? We are obviously not dealing with the real world here; we are in a world on the edge 
of possibility, or perhaps even in a multiple world, divided principally between the perceptual sphere of the "old" and that of the "young" or "new". Mendacity and irresponsibility are the elements of a sort of dream world in which the havocwreaker evolves, outside of the world of the others which is equally false because convention has cut them off from reality. In what world then is the havoc-wreaker supposed to know "what is really going on"?

As for the question of finding a "solution" to a "problem", it is obvious by looking at "Shock Tactics", as well as at many other stories, that no solution is offered. Clovis does not make Mrs. Heasant sound of mind, he only modifies her hierarchy of values; appearances take precedence over "moral" questions and she leaves to her son the "dissipation" of his private correspondence so as to keep up those appearances. Clovis liberates Bertie from one unpleasant situation, but brings no permanent order or sanity to either him or his mother. In his "hands off!" gesture, Clovis protects a young friend from one aspect of a mentality that he execrates but finds incurable. The only important thing is to stop this mentality from hampering the pleasure that these young people are looking for. Therefore other explanations for the modus operandi of the Sakian havoc-wreaker must be presented.

In the same way we can contrast these narratives and the actions of these comic heroes to Tom Docherty's comments. "The Schartz-Metterklume Method", "The Unrest-Cure", and "Shock Tactics" show Clovis and Lady Carlotta as they inventively do battle with the boredom which threatens the tidy middle class. We have seen the specifics of the havoc-wreakers' positions of responsibility or irresponsibility in connection with each narrative. But how does this comic context respond in general to Docherty's claims about irresponsibility and loss of self? As will be seen below, I find many relations between this question of responsibility or irresponsibility and others that equally pertain to Sakian methods. All these questions become perforce interwoven; I will attempt to keep the threads colorful enough so that we can distinguish them.

I would point out first that what both of these renamed and supposedly "irresponsible" characters are responsible for essentially is the complete if momentary disruption of complacency, routine, and dullness. They take these lives, toss them into the air, and let them fall where they will and in however many pieces. However, they were seen by the readers of the time as irresponsible, and in fact immoral. For example, an anonymous reviewer states: "round [Clovis] the most extraordinary things continually happen. Charming and amusing things, of course, and all so delightfully immoral" (Beasts 1911: 2). This condemnation is precisely uttered against the havoc-wreakers' very Sakian zest for "sacking" the conventionality of those surrounding them. These characters show a liberation from duty and appearances, and pursue pleasure. This search for pleasure - a main pursuit for satire, according to Christopher Herbert - suggests rather a-responsibility (1984: 401-416). Through this pleasurable supposed immorality, the havoc-wreakers send the comic message that hiding behind routine does not make a person responsible. Docherty, by bringing up the idea of irresponsibility, 
implicitly accuses such characters of shirking. The attacks perpetrated by Carlotta and especially Clovis indicate that what they do not shirk is an occasion to wake people up, to shake them out of their routine, if only for a time.

But more than that, the wiles of Saki beg for a definition of the comic that takes a different approach than that dealing with questions of responsibility or Bergsonian correction. Susanne K. Langer, in her work Feeling and Form, defines comic action as "the upset and recovery of the protagonist's equilibrium" (1953: 331). As "comedy is essentially contingent", it illustrates the capacity of those in the comic situation to deal with contingency, to accept the disequilibrium (Langer 1953: 333). Roger B. Henkle echoes this notion when he designates the comic vision as "a contingent, ever-changing reality dissolving old fictions and prompting new ones" (1980: 19). And certainly we can see the ability of these havoc-wreakers to create fictions, and the incapacity of the un-comic characters to even recognize, let alone create, a pleasurable fiction. They cling to the old, established fictions ferociously.

Through my readings of Langer and Henkle, as well as of Margaret Ganz, Stuart M. Tave, Ronald Paulson, Marcel Gutwirth, and Robert M. Torrance, I have devised a point of view of the comic hero as a person who functions well in a state of contingency. When routine or rhythm is disrupted, this character can roll with the punches, go with the flow, and land on his feet once the latest bout of uncertainty is resolved. He is always ready to ride the next bout, and may even provoke it himself. I would paraphrase these authors and answer Docherty by saying that the comic hero is a figure who can live through contingencies with the self intact. Whatever unexpected event presents itself - especially one constructed by the hero - that hero will arrive before the next wave of the unexpected still himself, identified, self-identified, and identifiable. The comic butt is caught between scrambling back into the identity attacked by this contingency and the realization that this identity is no longer sure.

This interpretation both responds to Docherty's concern for loss of self through the irresponsibility of renaming and aligns the comic hero with Susan Purdie's model of comic character-types based on Freud's division into types (Purdie 1993: 101-107). To Purdie the different oral and anal types of Freud's analytical concepts are the victims or butts, and the genital, mature types the hero. These genital types are opposed to the victims, whose self-image relies on an artificial and superficial stability that these genital types have so easily overthrown. It is doubly significative to remember that Freud saw the oral and anal types as not having arrived at a state of maturity, identified by a sense of true responsibility. Thus, to knit Docherty, Freud and Purdie together, those who are irresponsible are those who cling to their names and their customs in anal- or oral-receptive fashion, rather than those who brave the contingency of launching into a new identity and taking on the responsibility of testing names and norms.

We can see in the cases studied above that it is rather those who have struggled to keep their identities faced with the assault of the determined havoc-wreakers who have had their sense of self perturbed. Mrs. Quabarl finds herself out of con- 
trol of the conversation at the dinner table. The Huddles have been thrust out of their identifiable and identifying routine of curried duck and naps. Mrs. Heasant has actually been accused of "not being herself", not being in her right mind, not conforming to her image of herself. Clovis and Lady Carlotta, the name changers, have no such problems. They are able to ride through the contingencies of new identities supremely intact. Thus I argue a reversal of Docherty's suggestion; the juggling of naming does not threaten loss of self, but the juggling - and probably the rejection - of supposed certainties does. The comic hero, free in contingency, needs no certainty; the victim clings to his notion of certainties, defined by convention, in order to define his self. The outer and superficial is seen to define him, until the comic hero turns those definitions inside-out, separates the defined from the definition, and in and by that distance creates doubt.

It seems to me that this argument also parallels the reversal by Saki of some of Bergson's philosophical discussion in Le rire. Bergson says that laughter is what society engages in against the person who has been too individualistic or has in some way shown marked difference from society, somewhat like M Jourdain in Le Bourgeois Gentilhomme (Bergson 1970: 472). Saki obviously presents the contrary, an individual who has freed himself from society's constraints and laughs at it from outside the closed circle of that society's perceptions. It is those who show no marked difference from society who are the butts in these narratives. Saki's characters thus show an evolution in society.

It is interesting to note corroboration of this reversal of dynamic in other sources. Literary editor J. W. Lambert illustrates the same opposition of free individual to closed society when he indicates that in Saki's first novel, The Unbearable Bassington, "Its villain is a grossly materialistic society, its victim a free spirit who, born and bred to the conventional world, can neither conform nor totally cut himself off" (1963: 45). Comus, the hero of the novel, launches himself into the contingency of pranks and insouciance, but as he is dependent on the society that creates the conformities, he is unable to step out of it unscathed. His is the only example of unsuccessful havoc-wreaking; all the other Sakian heroes survive intact.

Lambert goes on to say that Saki's humor "points, with hypnotic glee, towards the fragmentation of established society, the confusion of the bourgeoisie" (1963: 60). Historian George Dangerfield saw this same disintegration:

For nearly a century men had discovered in the cautious phrase, in the respectable gesture, in the considered display of reasonable emotions, a haven against those irrational storms which threatened to sweep through them. And gradually the haven lost its charms; worse still, it lost its peace. Its waters, no longer unruffled by the wind, ceased to reflect, with complacent ease, the settled skies, the untangled stars of accepted behaviour and sensible conviction: and men, with a defiance they could not hope to understand, began to put forth upon little excursions into the vast, the dark, the driven seas beyond (1936: 135). 
Dangerfield maps in the macro environment what Saki was exploiting in his microenvironment of the short story. We see here that Saki's minor destruction of society through pranks and acid comments was part of a larger movement that can be observed by other experts.

These comments by George Dangerfield are mirrored in those of other authors. Philippe Garner makes a similar observation, but situates the beginning of the movement at the end of Victoria's reign: "“the naughty ' 90 s' can be considered as the accelerating pursuit of an image of excitement and escape. [...] the minds of the 1890s had an insatiable thirst for sensation" (1974: 28). In the same vein, Anne Clark Amor evokes the sense of provocation contained in Oscar Wilde's lodging of a complaint against the Marquess of Queensberry (1985: 208).

Dangerfield's comments also find many echoes in studies of perception. Ezra Pound considered artists the "antennae of the race" (1934: 630). He represents them as anticipating the changes in a given society's perceptions. Such a change in perception is described above by Dangerfield, and noted post facto by Mais, who identifies Saki's attacks on "worship at the shrine of convention" (1920: 329). Marshall McLuhan informs us that "[e]very culture and every age has its favorite model of perception and knowledge that it is inclined to prescribe for everybody and everything" (1964: 21). There is a model for the Mrs. Heasants and the Huddles. It is the same model for Bergson. The person operating from an outside position avoids being trapped in such models. For Bergson and the average Sakian victim, that outside position is reprehensible; thus the "immorality" of the Sakian hero, a loss of recognizable identity to society. "Immoral" is here a synonym for "abnormal", not adhering to accepted norms.

For the havoc-wreaker, it is otherwise. Outside the norms of this society, he can observe the absurdity of those norms and avoid being overcome by them, and thus he can preserve his sense of self, and in fact assert his self. This is what the Sakian havoc-wreaker does as he revels in the a-responsibility of his enjoyment of contingency. These three stories, while they upend the complacency of the staid characters upon whom different pranks are visited, also tip over, Till Eulenspiegel-wise, the apple-carts of the best-laid analyses of Docherty, Drake, Bergson. And they do so while the play of names is at what Docherty would find the most alarming level, when the main characters are supposed to suffer from their unstable identities. Instead it is the supposedly stable who suffer. Docherty refers to "experimental fiction", and indeed Clovis and Carlotta experiment with the rabbits of the conventional life around them. The results of these experiments demonstrate the solidity of their selves in the face of contingency, which they embrace, and the fragility of identity of those who flee contingency. All of these considerations point to Saki's naming game as indicative of his own position. It constitutes another element of his "lynx in the drawing room" attitude to his time, a time that he was in but not of (Pritchett 1957: 19).

Ultimately, this is the final proof of Saki as an artist. In his assessment of artists as announcers of shift, McLuhan states: "In the history of human culture there is no example of a conscious adjustment of the various factors of personal and so- 
cial life to new extensions excepting in the puny and peripheral efforts of artists. The artist picks up the message of cultural and technological challenge decades before its transforming impact occurs" (1964: 70). For McLuhan, as for Pound, artists are forecasters of shifts in perception. As they are, by their profession, immersed in questions of perception, they are the first to register these changes, either consciously or intuitively. Clovis and Carlotta, the artists in mendacity and social legerdemain, anticipate the liberating from the false sense of responsibility of a culture containing too many Huddles and Quabarls for their taste. Thus they reflect their creator, "sacking" the crumbling haven and launching hero and victim alike on a sea of contingency.

\section{References}

Abrams, Fred (1971) "Onomastic Humor in Saki's 'Filboid Studge, the Story of a Mouse that Helped"”. Names 19 (4), 287-288.

Amor, Anne Clark (1985) Madame Oscar Wilde. Paris: Perrin.

Arthur, William (1857) An Etymological Dictionary of Family and Christian Names. With an Essay on Their Derivation and Import. New York: Sheldon, Blakeman \& Co..

Bergson, Henri (1970) Le rire: Essai sur la signification du comique. Euvres. Paris: Presses Universitaires de France, 381-485.

"Beasts and Super-Beasts" (1914) Review of Beasts and Super-Beasts by Saki. Spectator 11 July, 61.

Bilton, Peter (1966) "Salute to an N.C.O.". English Studies 47 (6), 439-442.

Birden, Lorene M. (1996) 'One's bitterest friends': dynamique de caractère et humour chez Saki. Diss. Université de Nice.

Birden, Lorene M. (2011) “Cross Purposes or Crossing Borders? Saki's Mix of Reporting and Fiction”. Annals of 'Dunărea de Jos' University of Galaţi Fascicle XIII, Language and Literature, Year XXIX, Issue 30, 1-19.

Chambers Concise Dictionary (2009) Edinburgh: Chambers Harrap.

Charnock, Richard Stephen (1882) Prænomina; or, The Etymology of the Principal Christian Names of Great Britain and Ireland. London: Trübner \& Co..

Cresswell, Julia (2003) Collins Dictionary First Names. Glasgow: HarperCollins.

"Dagmar". http://www.thinkbabynames.com/meaning/0/Dagmar

Dangerfield, George (1936) The Strange Death of Liberal England. New York: Harrison Smith and Robert Haas.

Didion, Joan (1979) “A Preface”. Slouching Toward Bethlehem. New York: Touchstone-Simon and Schuster, xi-xiv.

Digamma (1904) “The Brilliant Young Man”. Westminster Gazette 16 Jan, 1-2.

Docherty, Tom (1983) Reading (Absent) Character: Towards a Theory of Characterization in Fiction. Oxford: Clarendon.

Drake, Robert (1960) "The Sauce for the Asparagus: A Reappraisal of Saki”. The Saturday Book. $\mathrm{N}^{\circ}$ 20. London: Hutchinson, 61-73.

"Ella". http://www.thinkbabynames.com/meaning/0/Ella

Ganz, Margaret (1990) Humor, Irony, and the Realm of Madness: Psychological Studies in Dickens, Butler, and Others. New York: AMS.

Garner, Philippe (1974) The World of Edwardiana. London: Hamlyn.

Gillen, Charles H. (1969) H. H. Munro (Saki). New York: Twayne.

Gutwirth, Marcel (1993) Laughing Matter: An Essay on the Comic. Ithaca: Cornell University Press. 
Hanks, Patrick, and Flavia Hodges (eds.) (1994) A Dictionary of First Names. Oxford: Oxford University Press.

Hanks, Patrick, Kate Hardcastle, Flavia Hodges (eds.) (2006) A Dictionary of First Names. Oxford Reference Online. Oxford University Press. King's College Library. 8 Feb. http://www.oxfordreference.com/views.ENTRY.html?subview=Main\&entry=+41.e4336

Henkle, Roger B. (1980) Comedy and Culture: England 1820-1900. Princeton: Princeton University Press.

Herbert, Christopher (1984) "Comedy: The World of Pleasure". Genre 17 (4), 401-416.

"Holy Grail". http://www.encyclopedia.com/topic/sangrail.aspx

Hynes, Samuel (1968) The Edwardian Turn of Mind. London: Oxford University Press.

Khayyam, Omar (2010) The Rubáiyát of Omar Khayyám. Trans. Edward FitzGerald.

$\mathrm{http} / / /$ emotional-literacy-education.com/classic-books-online-a/rubai10.htm

"Klum". http://german.about.com/od/names/a/gerNames_2.htm

Knowles, Elizabeth (ed.) (2006) The Oxford Dictionary of Phrase and Fable. Oxford: Oxford University Press.

"Krume/Klemme/Klumm". http://www.wordreference.com/krume

Lambert, J. W. (1963) Introduction. The Bodley Head Saki. London: The Bodley Head, 7-62.

Langer, Susanne K. (1953) Feeling and Form: A Theory of Art Developed from Philosophy in a New Key. London: Routledge and Kegan Paul.

Langguth, A. J. (1981) Saki: A Life of Hector Hugh Munro. New York: Simon and Schuster.

Mais, S. P. B. (1920) "The Humor of 'Saki"'. Books and their Writers. London: Grant Richards, 311-330.

McLuhan, Marshall (1964) Understanding Media: the Extensions of Man. New York: Signet-New American Library.

Milne, A. A. (1926) "Introduction". The Chronicles of Clovis. The Collected Works of Saki. London: John Lane The Bodley Head, ix-xii.

Munro, Ethel M. (1930) "Biography of Saki”. The Complete Works of Saki. By Saki. 2 vols. London: John Lane The Bodley Head, 2: 635-715.

Nänny, Max (1984) "Narrative Modes of Communication". In: Mortimer, Anthony (ed.) Contemporary Approaches to Narrative. Tübingen: Narr, 51-62.

Nasr, S. H. (2006) “The Poet-Scientist 'Umar Khayyám as Philosopher”. Islamic Philosophy from Its Origin to the Present: Philosophy in the Land of Prophecy. Albany: SUNY Press, 165-184.

"Nitchevo" (1916) "Lilian's Lonely Soldier". Bystander 20 September, 511-512.

Ong, Walter (1982) Orality and Literacy: The Technologizing of the Word. London: Methuen.

Paulson, Ronald (1998) Don Quijote in England: The Aesthetics of Laughter. Baltimore: Johns Hopkins University Press.

Pound, Ezra (1934) “The Teacher's Mission”. The English Journal 23 (8), 630-635.

Pritchett, V. S. (1957) “The Performing Lynx”. New Statesman 53.1347, 18-19.

Pritchett, V. S. (1963) "Saki”. New Statesman 66.1703, 614-615.

Purdie, Susan (1993) Comedy: The Mastery of Discourse. London: Harvester Wheatsheaf.

"Rail". http://dictionary.reference.com/browse/rail+against?qsrc=2446

"Reginald's Successor" (1911) Review of The Chronicles of Clovis by Saki. Morning Post 23 Oct, 2.

Saki [Hector Hugh Munro] (1902a) "The Political Jungle-Book: The Wolf-Pack and Others". Westminster Gazette 11 Feb, 1, 2.

Saki [Hector Hugh Munro] (1902b) "The Political Jungle-Book II - the Dancing of Mor. Mor the Peacock. The Stampede of Runamukki”. Westminster Gazette 21 Apr, 3.

Saki [Hector Hugh Munro] (1909) “The Sex that Doesn't Shop”. Westminster Gazette 27 March, 2. Saki [Hector Hugh Munro] (1910a) "The Unrest-Cure". Westminster Gazette 1 April, 1, 2.

Saki [Hector Hugh Munro] (1910b) "Ministers of Grace". Bystander 30 Nov, 432-434.

Saki [Hector Hugh Munro] (1911) "The Schartz-Metterklume Method". Westminster Gazette 14 Oct, 2. 
Saki [Hector Hugh Munro] (1912a) "Ministers of Grace". The Chronicles of Clovis. London: John Lane The Bodley Head, 266-285.

Saki [Hector Hugh Munro] (1912b) "The Unrest-Cure". Chronicles of Clovis 73-85.

Saki [Hector Hugh Munro] (1914a) "The Lull”. Beasts and Super-Beasts. London: John Lane The Bodley Head, 73-81.

Saki [Hector Hugh Munro] (1914b) “The Open Window”. Beasts and Super-Beasts 50-55.

Saki [Hector Hugh Munro] (1914c) "The Quince Tree". Beasts and Super-Beasts 183-189.

Saki [Hector Hugh Munro] (1914d) "The Schartz-Metterklume Method”. Beasts and Super-Beasts 97-105.

Saki [Hector Hugh Munro] (1914e) "A Touch of Realism”. Beasts and Super-Beasts 133-142.

Saki [Hector Hugh Munro] (1914f) "Potted Parliament". The Outlook 16 May, 677-678.

Saki [Hector Hugh Munro] (1919) "Shock Tactics". The Toys of Peace. London: John Lane The Bodley Head, 217-226.

"Sangfroid". http://dictionary.reference.com/browse/sangfroid

"Sanguinary". http://dictionary.reference.com/browse/sanguinary

"Scat". http://dictionary.reference.com/browse/scat

"Schartz/ Schatz/ Schar". http://answers.yahoo.com/question/index?qid=20090219001 106AACQ6mT

"Schartz/ Schatz/ Schar." http://www.wordreference.com/schartz

Spears, G. J. (1963) The Satire of Saki. New York: Exposition.

Tave, Stuart M. (1960) The Amiable Humorist: A Study in the Comic Theory and Criticism of the Eighteenth and Early Nineteenth Centuries. Chicago: University of Chicago Press.

Thrane, James R. (1971) “Two New Stories by 'Saki’ (H. H. Munro)”. Modern Fiction Studies 19, $139-151$.

Torrance, Robert M. (1978) The Comic Hero. Cambridge: Harvard University Press.

"Violet". http://www.thinkbabynames.com/meaning/0/Violet

Weekley, Ernest (1916) Surnames. London: John Murray.

LORENE M. BIRDEN is a literary researcher and translator. Drawing on studies leading to doctoral degrees in French and Russian literature from the University of Massachusetts (1993), and in English literature from the Université de Nice (1996), she has focused on nineteenth- and twentieth-century prose fiction, producing studies on Triolet, Flaubert, Zola, Chekhov, Pasternak, Eliot, Anne Brontë, and Saki, and translations of Triolet, Cixous, Jacob, and Chekhov. This diversity of background has also allowed her to develop projects in comparative literature, with studies on Russian/French or French/English connections. She is currently a member of the British Association for Victorian Studies and the International Society for Humor Studies; the latter activity has allowed Dr. Birden to concentrate on the short story and to begin developing projects on humor in the short story in collaboration with other members of the society. She is maitre de conférences at the Institut Universitaire de Technologie in Dijon, France.

Address: Dr Lorene M. Birden, 46 rue Chaudronnerie, 21000 Dijon, France. [e-mail: lorene.birden@iut-dijon.u-bourgogne.fr] 